\title{
PENGARUH CARA PENGOLAHAN TERHADAP AKTIVITAS ANTIOKSIDAN EKSTRAK BAWANG PUTIH (Allium sativum L.) VARIETAS KATING DAN SINCO
}

\author{
Ir. Sudjatini, M.P.
}

\begin{abstract}
Research with the title aruh Effect of Processing Method on Antioxidant Activity of Garlic Extract (Allium sativum L.) varieties of Kating and Sinco ', aims to determine the antioxidant activity of Kating and Sinco varieties of garlic in several processing methods. The design used in this study is a Completely Randomized Design (CRD) with a factorial pattern consisting of two factors. First the garlic variety factor consisted of 2 treatments namely Kating and Sinco Varieties; The second factor of processing method consists of 3 treatments namely Raw, Fried and Boiled. The data obtained was carried out an analysis of variance (ANAVA), if there were differences between treatments, further tests were performed using Duncan's Multiple Ranges Test (DMRT) at the 5\% level.The results showed that differences in processing methods and differences in garlic varieties significantly affected the chemical properties of garlic extracts, namely the water content and antioxidant activity. The antioxidant activity of the Kating variety raw garlic extract is higher than the Sinco variety, however, Sinco garlic has a higher antioxidant stability against heatprocessing, ie by frying and boiling method than the Kating variety.
\end{abstract}

Keywords: garlic, antioxidants, DPPH test

\begin{abstract}
ABSTRAK
Penelitian dengan judul 'Pengaruh Cara Pengolahan terhadap Aktivitas Antioksidan Ekstrak Bawang Putih (Allium sativum L.) varietas Kating dan Sinco', bertujuan untuk mengetahui aktivitas antioksidan bawang putih varietas Kating dan Sinco pada beberapa metode pengolahan.Rancangan yang digunakan dalam penelitian ini adalah Rancangan Acak Lengkap (RAL) dengan pola factorial yang terdiri dua factor. Pertama factor varietas bawang putih terdiri dari 2 perlakuan yaitu Varietas Kating dan Sinco; kedua factor metode pengolahan terdiri 3 perlakuan yaitu Mentah, Goreng dan Rebus. Data yang diperoleh dilakukan analisis of varians (ANAVA), apabila terdapat perbedaan antar perlakuan dilakukan uji lanjutan dengan metode Duncan's Multiple Ranges Test (DMRT) pada jenjang 5\%. Hasil penelitian menunjukkan bahwa perbedaan cara pengolahan dan perbedaan varietas bawang putih berpengaruh nyata terhadap sifat kimia ekstrak bawang putih, yaitu terhadap kadar air dan aktivitas antioksidannya. Aktivitas antioksidan ekstrak bawang putih mentah varietas Kating lebih tinggi daripada varietas Sinco, namun demikian bawang putih Sinco memiliki stabilitas antioksidan yang lebih tinggi terhadap pengolahan yang menggunakan panas, yaitu dengan cara penggorengan dan cara perebusan dibandingkan varietas Kating
\end{abstract}

Kata kunci : bawang putih, antioksidan, uji DPPH

\section{PENDAHULUAN}

\section{Latar Belakang}

Bawang putih (Allium sativum L.)merupakan salah satu komoditas yang sangat penting karena memiliki banyak kegunaan, terutama sebagai bahan penyedap masakan dan bahan obat-obatan (Budi, 2004, Lee, et al., 2000 dalam Hernawan dan Setyawan, 2003).
Informasiawal tentang khasiat obat yang berasal dari tanaman dimulai sekitar tahun 3000 SM oleh bangsa Cina (Raskin, et al., 2002;Banerjee dan Maulik, 2002 dalam Octaviantie, et al., 2017), dan suku-suku pengelana Asia Tengah yang menggunakannya untuk menjaga kesehatan.

Umbi bawang putih mengandung senyawa allisin dan scordinin yang merupakan zat antibiotika dan merupakan zat yang dapat 
memberikan kekuatan daya tahan tubuh.Bawang putih juga dikenal sebagai bahan penyedap masakan dan sangat disukai masyarakat karena memiliki aroma yang pedas dan harum karena mengandung senyawa methyl allyl disulfideyang membuat masakan lebih enak(Yuli, 2014). Hal ini tidak lepas dari kandungan senyawa aktif dalam bahan dan sifat antioksidan dari senyawa tersebut.Namun sampai kini masih belum diketahui seberapa besar aktivitas antioksidan dalam umbi bawang putih dengan adanya perbedaan metode pengolahan yang lazim dilakukan masyarakat. Dalam penelitian iniakan dilihat pengaruh cara pengolahan terhadap aktivitas antioksidan dari bawang putih varietas Kating dan varietas Sinco.

\section{TujuanPenelitian}

Penelitian ini bertujuan untuk membandingkan aktivitas antioksidan dari bawang putih varietas Kating dan Sinco pada berbagai cara pengolahan. Cara pengolahan yang digunakan adalah mentah, direbus dan digoreng, mengikuti cara pengolahan bawang putih yang dilakukan oleh masyarakat umum dalam kehidupan sehari-hari. Dari hasil penelitian ini diharapkan dapat diketahui pengaruh cara pengolahan bawang putih terhadap aktivitas antioksidan bawang putih varietas Kating dan varietas Sinco, sehingga cara pengolahan tersebut dapat menjadi alternatif dalam mempertahankan aktivitas antioksidan dalam bahan.

\section{TINJAUAN PUSTAKA}

Menurut Octaviantie et al., (2017) bawang putih adalah salah satu tanaman obat paling tua yang berasal dari benua Asia. Bawang putih memiliki beragam efek positif untuk kesehatan, antara lain bersifat antibakteri, anti virus, anti jamur, dan antioksidan. Selain itu bawang putih juga memiliki banyak efek positif untuk system kardiovaskuler, antara lain menyebabkan penurunan tekanan darah, mencegah terjadinya aterosklerosis, dan juga bersifat antitrombotik.

Sebagai bahan penyedapmasakan, bawang putih sangat disukai masyarakat karena memiliki aroma yang pedas dan harum disebabkan oleh kandungan senyawa methyl allyl disulfide yang membuat makanan lebih terasa enak. Oleh sebab itu, bawang putih selalu menjadi bumbu utama pada setiap hasil olahan yang melalui proses pemasakan (Budi, 2004).

Tanaman bawang putih tergolong genus Allium, family Liliales/ Lilliaceae dan spesies Allium sativum L. Menurut Thomas, 2000 dalam Hernawan dan Setyawan, 2003; bagian tanaman bawang putih yang paling berkhasiat adalah bagian umbi. Namun umbi bawang putih memiliki bau sangat menyengat, yang berasal dari kandungan minyak atsirinya.Oleh sebab itu umbi bawang putih tidak biasa dimakan dalam keadaan mentah secara langsung, melainkan digunakan sebagai bahan penyedap masakan (Yuli, 2014).

\section{Komponen-komponen Sulfida dalam Bawang Putih}

Dalam umbi bawang putih terdapat banyak komponenyangsebagian besar mengandung sulfur. Bawang putih yang dihancurkan akan mengubah senyawa thio sulfonat menjadi sulfida secara spontan. Komponen sulfida utama yang terbentuk adalah: allisin, diallil disulfida, diallil trisulfida dan metil allil trisulfida (Wade, 2003; Nicolic, dkk. 2004 dalam Yuniastuti 2006), senyawa allisin merupakan salah satu komponen aktif yang utama dalam bawang putih yang mempunyai efek antibakteri, antioksidan, dan anti karsinogenik. Allisin terbentuk dari reaksi antara enzim alliinase dan suatu bahan asam amino nonprotein yang disebut dengan alliin.Gugus SO- yang dimiliki allisin menyebabkan bau yang khas pada bawang 
putih. Namun demikian, senyawa allisin bersifat tidak stabil, dan hanya bertahan sebentar dan segera akan mengalami degradasi (North and Quadrini, 2001; Atmadja, 2002; dalam Yuniastuti, 2006).

Rumus molekul senyawa Allicin, dapat dilihat pada Gambar 1.

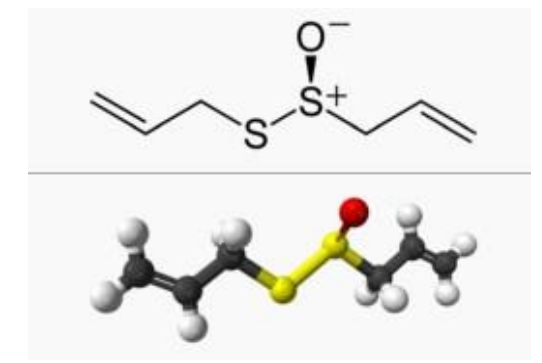

Gambar 1. Struktur Allicin (Anonim, 2018)

Hernawan dan Setyawan (2003); menyatakan bahwa sebagai bahan obat-obatan, umbi bawang putih berkhasiat menyembuhkan penyakit tekanan darah tinggi (hipertensi), penyakit kencing manis (diabetes), penyakit infeksi saluran pernafasan, penyakit cacingan, penyakit infeksi pada usus, penyakit infeksi pada kulit, luka gigitan binatang berbisa, penyakit batuk, gatal-gatal, penyakit thipus, penyakit meningitis karena jamur, penyakit kelamin (gonorrhoe), penyakit maag, penyakit kanker, dan mata bengkak karena angin. Bahkan bawang putih juga memiliki sifat antitrombotik yaitu dapat mencegah pembekuan darah (Octaviantie, et al. 2017).

\section{Sifat Antioksidan Bawang Putih}

Sifat antioksidan merupakan parameter yang sangat penting dalam mengembangkan pangan fungsional. Sifat tersebut berupa kadar senyawa antioksidan yang menunjukkan tingkat aktivitasnya sebagai antioksidan. Menurut Asep, dkk. 2012; senyawa antioksidan adalah senyawa yang ketika berada dalam konsentrasi rendah dibandingkan dengan substrat, dapat dioksidasi dan secara nyata dapat memperlambat oksidasi substrat tersebut.
Antioksidan akan bereaksi dengan oksidan sehingga mengurangi kapasitas oksidan untuk dapat menimbulkan kerusakan (Shahidi, 1997; dalam Asep, 2012).

Menurut Gebreyohannes, 2013; Darmadi, dkk. 2013, dan Haryati, 2014; dalam Sulistyorini (2015), senyawa antioksidan dalam umbi bawang putih adalah Allicin, yang berupa senyawa polar, fenolik dan steroid. Sementara itu Siswono (2005) dalam Sulistyorini (2015) menyatakan bahwa radikal bebas yang berada dalam tubuh manusia adalah berupa superoksida, hidroksil, peroksil, hydrogen peroksida dan oksida nitrit. Sedangkan radikal bebas dari luar tubuh bisa berasal dari asap rokok, polusi, radiasi, sinar UV, obat, pestisida, limbah industry, dan ozon. Radikal bebas yang berlebihan di dalam tubuh dapat menyebabkan kerusakan sel-sel jaringan dan enzim-enzim.

Menurut Sulistyorini (2015), antioksidan yang dimiliki bawang putih dapat memberikan mekanisme pertahanan terhadap radikal bebas. Penggunaan antioksidan yang berasal dari bahan alami cenderung lebih aman dibandingkan dengan antioksidan yang sintetik, karena antioksidan sintetik dapat bersifat karsinogenik dan toksik pada tubuh manusia.Hal ini dipertegas dengan pernyataan Steinberg (2010) dalam Sulistyorini (2015) bahwa antioksidan sintetik seperti BHT dan BHA dapat bersifat karsinogenik dan toksik bagi system imun, kulit, paru-paru dan hati.

\section{METODE PENELITIAN}

\section{Tempat, Bahan dan Alat Penelitian}

Penelitian dilakukan di laboratorium Kimia Pangan \& Gizi, laboratorium Rekayasa Fakultas Teknologi Pertanian Universitas Widya Mataram Yogyakarta dan di CV. Chemic Pratama Yogyakarta.

Bahan utama yang digunakan adalahumbi bawang putih varietas Sinco dan varietas Kating 
serta minyak goreng merk 'Bimolli', diperoleh di Toko Superindo, Yogyakarta. Sedang bahan kimia dan bahan lain terdiri dari Asam klorida, ethanol, reagen DPPH, aquades, kain saring, dan kertasalumunium foil, diperoleh dari Laboratorium Kimia Pangan Fakultas Teknologi Pertanian Universitas Widya Mataram.

Alat-alatyang digunakanmeliputinampan, baskom, pisaudan panci stainless-stell,blender, alat penggorengan, alat pengaduk, komporlistrik, kompor gas, gelas ukur, beker glas, timbangan, thermometer, pipet volume, erlenmeyer,waterbath, dan spectrofotometer.

\section{MetodePenelitian}

Penelitianiniterdiridaridua

tahapan,yaitu:tahap1) ekstraksi umbi bawang putih pada berbagai kondisi pengolahan (mentah, rebus, goreng) dan tahap 2) analisis aktivitas antioksidan ekstrak bawang putih yang dihasilkan.

\section{Ekstraksi Bawang Putih}

Prosesekstraksi bawang putih menggunakan metode yang dilakukan oleh Oktaviantie, et al, 2017. Prosesekstraksi bawang putih mentah dibuat dengan cara menghancurkan bawang putih yang sudah dikupas dan dicincang dengan blender, hasilnya diperas menggunakan kain saring. Kelompok bawang putih rebus dibuat dengan cara merebus hasil cincangan bawang putih kupas dengan air sampai mendidih ( \pm 6 menit), kemudian bawang putih diblender dan hasilnya diperas menggunakan kain saring. Kelompok bawang putih goreng dibuat dengan cara menggoreng hasil cincangan bawang putih kupas sampai berwarna kuning keemasan, selanjutnya di blender dan diperas dengan kain saring.

\section{Analisis aktivitas antioksidan Bawang Putih dengan metode DPPH}

Aktivitas antioksidandalam ekstrak bawang putih dianalisa berdasarkan kemampuan dari senyawa polifenol dalam bawang putih untuk menangkap radikal (radical scavenging activity) DPPH (1-1-diphenyl-2picrylhydrazyl) (Amin dan Lee, 2005).

Sebanyak $0,01 \mathrm{ml}$ filtrat bawang putih dimasukkan ke dalam tabung reaksi, kemudian ditambahkan 0,5 ml larutan DPPH $400 \mu \mathrm{M}$. Campuran ditera dengan etanol sampai $5 \mathrm{ml}$ dan dihomogenkan dengan menggunakan vortek. Setelah itu didiamkan selama 20 menit dan kemudian diukur nilai absorbansinya pada panjang gelombang $517 \mathrm{~nm}$ dengan menggunakan spektrofotometer.Aktivitas antioksidan dinyatakan dalam $\mathrm{mmol} / \mathrm{g}$.

\section{Rancangan Percobaan}

Rancangan percobaan yang digunakan dalam penelitian ini adalah rancangan acak lengkapyang disusunsecara faktorial.Faktorpertama yaitu varietas bawang putih terdiri dari varietasSinco dan varietas Kating; danfaktorkedua yaitu metode pengolahan bawang putih terdiri : bawang mentah, rebus, dan goreng. Ekstrak bawang putih yang dihasilkan kemudian dilakukan analisa kimia yang meliputi analisa kadar air dan aktifitas antioksidan. Data yang diperoleh dilakukan analisa variasi (ANOVA), apabila terdapat perbedaan uji nyata dilakukan uji lanjutan dengan metoda Duncan's Multiple Range Test (DMRT) pada taraf signifikansi 5\%.

\section{HASIL PENELITIAN}

\section{Kadar Air}

Hasil rerata analisa kadar air dan aktivitas antioksidan ekstrak bawang putih dapat dilihat pada Tabel 1. 
Tabel 1. Kadar Air (\%) dan Aktivitas Antioksidan (\% RSA) Ekstrak Bawang PutihVarietasKating dan Sinco pada Metode Pengolahan Mentah, Goreng, dan Rebus.

\begin{tabular}{|c|c|c|c|}
\hline $\begin{array}{c}\text { Metode } \\
\text { Pengolahan }\end{array}$ & $\begin{array}{c}\text { Varietas } \\
\text { Bawang } \\
\text { Putih }\end{array}$ & $\begin{array}{c}\text { Kadar } \\
\text { Air (\%) }\end{array}$ & $\begin{array}{c}\text { Aktivitas } \\
\text { Antioksidan } \\
(\% \text { RSA })\end{array}$ \\
\hline MENTAH & Kating & $65,39 \mathrm{~d}$ & $47,41 \mathrm{a}$ \\
\hline & Sinco & $68,69 \mathrm{c}$ & $40,65 \mathrm{~b}$ \\
\hline GORENG & Kating & $45,11 \mathrm{f}$ & $14,44 \mathrm{e}$ \\
\hline & Sinco & $45,87 \mathrm{e}$ & $26,12 \mathrm{c}$ \\
\hline REBUS & Kating & $76,56 \mathrm{~b}$ & $14,29 \mathrm{e}$ \\
\hline & Sinco & $79,64 \mathrm{a}$ & $19,98 \mathrm{~d}$ \\
\hline
\end{tabular}

Keterangan : Angka yang diikuti dengan notasihuruf yang sama menunjukkanbahwa antar perlakuan tidak berbeda nyata pada taraf signifikansi5\%.

Berdasarkan hasil uji statistic pada taraf signifikansi 5\% (Tabel 1) menunjukkan bahwa ada interaksi antara kedua factor perlakuan yaitu factor varietas dan factor metode pengolahan. Dengan metode pengolahan mentah, goreng dan rebus, bawang putih Kating maupun Sinco menunjukkan interaksi yang sangat nyata terhadap kadar air ekstrak bawang putih yang dihasilkan. Dengan perlakuan penggorengan, berpengaruh secara nyata terhadap kadar air ekstrak bawang putih mentah maupun bawang putih rebus dan menjadi lebih rendah daripada bawang putih mentah maupun rebus, baik untuk varietas Kating maupun Sinco. Hal ini terjadi karena selama proses penggorengan dengan media pemanas minyak goreng, terjadi penguapan air dari bahan yang digoreng. Sedang pada proses perebusan media pemanas adalah air, maka akan terjadi proses penyerapan air ke dalam bawang putih yang lebih besar daripada penguapan air, sehingga kadar airnya menjadi bertambah besar dan berbeda nyata dengan bawang putih mentah. Hal ini terjadi pada kedua varietas bawang putih yaitu varietas Kating dan Sinco.Untuk lebih jelasnya dapat dilihat pada Gambar 2.

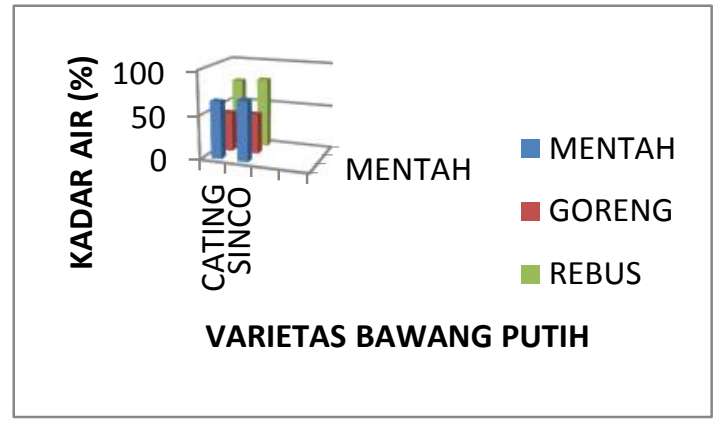

Gambar 2.Grafik Kadar Air Ekstrak Bawang Putih varietas Kating dan Sinco pada berbagai Metode Pengolahan.

\section{Aktivitas Antioksidan}

Hasil rerata analisa aktivitas antioksidan ekstrak bawang putih dapat dilihat pada Tabel 1 dan Gambar 3. Aktivitas antioksidan pada ekstrak bawang putih seperti terlihat pada Tabel 1 menunjukkan bahwa metode pengolahan bawang putih direbus maupun digoreng berpengaruh sangat nyata terhadap aktivitas antioksidan ekstrak bawang putih, untuk varietas Kating atau Sinco; dan berbeda nyata dengan aktivitas antioksidan ekstrak bawang putih mentah.Untuk varietas Kating, dengan metode perebusan maupun penggorengan, menunjukkan hasil yang tidak berbeda nyata. Yang menarik adalah bahwa ternyata varietas Sinco memiliki stabilitas antioksidan yang lebih tinggi dibandingkan dengan varietas Kating, hal ini ditunjukkan bahwa dengan direbus/digoreng nilainya masih tinggi.

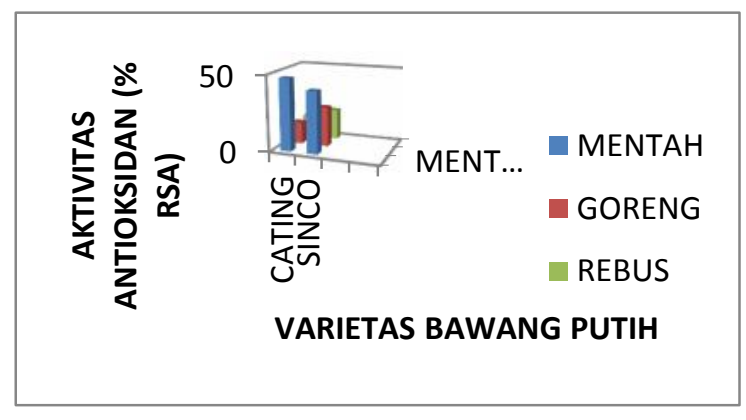

Gambar 3.Grafik Aktivitas AntioksidanEkstrak Bawang Putih Kating dan Sinco pada berbagai Metode Pengolahan. 
Menurut Octaviantie et al, 2017, bawang putih selama proses perebusan akan mengalami perubahan kadar allicinnya. Pada 3 menit pertama masih sama dengan kadar allicin bawang putih mentah, setelah itu kadar allicin terus menurun dan tidak terditeksi pada menit ke-6 perebusan.

Schwartz et al., (2002) dalam Hernawan dan Setyawan, (2003), mengatakan bahwa senyawa allicin merupakan antioksidan utama dalam umbi bawang putih yang mampu menekan produksi nitrat oksida. Akumulasi NO akan menginduksi pembentukan oksidator kuat, yaitu peroksinitrit. Nitrat oksida (NO) dapat dihasilkan dari asam amino arginin dengan bantuan enzim nitrat oksida sintase.Penurunan aktivitas antioksidan ekstrak bawang putih rebus dan goreng kemungkinan diakibatkan karena senyawa aktif pada bawang putih, yakni senyawa allicin yang bersifat termolabil mengalami degradasi karena panas (Velliyagounder, 2012; dalam Octaviantie, et al., 2017).

\section{KESIMPULAN}

Berdasarkan hasil penelitian, dapat disimpulkan bahwa metode pengolahan berpengaruh nyata terhadap kadar air dan sifat antioksidan ekstrak bawang putih varietas Kating dan Sinco.

Aktivitas antioksidan ekstrak bawang putih mentah varietas Kating lebih tinggi daripada bawang Sinco, namun bawang putih Sinco memiliki karakteristik stabilitas antioksidan yang lebih tinggi terhadap panas, yaitu dengan penggorengan dan perebusan dibandingkan dengan varietas Kating.

\section{DAFTARPUSTAKA}

Amin, I dan Lee, WY., 2005. Effect of different blanching on Antioxidant properties in selected

Cruciferous
Vegetables.Journal of the Science of Food and Agriculture. 85 (13): 21342320 .

Anonim, 2018.https//macorp.co.id/Pengertian \& Struktur Allisin, StrukturAllicin Allicin.https://www.khasiat.co.id/umbi/ba wang putih.html.

Asep, W. Permana, SM. Widayanti, S. Prabawati, dan D.A. Setyabudi, 2012.Sifat Antioksidan Bubuk Kulit Buah Manggis (Garcinia mangostana L.) instan dan Aplikasinya untuk Minuman Fungsional Berkarbonasi. J. Pascapanen 9(2) 2012 8895. Balai Besar Penelitian \& Pengembangan Pasca Panen Pertanian, Bogor.

Budi Samadi, 2004. Usaha Tani Bawang Putih: Pengembangan Bawang Putih Dataran Tinggi dan Bawang Putih Dataran Rendah. Cetakan ke-5.Penerbit Kanisius Yogyakarta.

Hernawan,UE dan Setyawan, AD. 2003. Review: Senyawa OrganosulfurBawang Putih

(Allium sativum L.)dan Aktivitas Biologinya. Jurnal Biofarmasi 1 (2): 65-76, ISSN: 1693-2242, FMIPA - UNS Surakarta.

Octaviantie, PD., Sri Purwaningsih, dan Arifoel Hajat. 2017. Pengaruh cara pengolahan bawang putih (Allium sativum) terhadap efek antitrombotik pada mencit. Jurnal Kedokteran Syiah Kuala, Vol. 17, Number 3, 157-160. ISSN: 1412-1026.

Sulistyorini, A., 2015. Potensi Antioksidan dan Antijamur Ekstrak Umbi Bawang Putih (Allium sativum L.) dalam Beberapa Pelarut Organik.Skripsi. Jurusan Biologi Fakultas Sains \& Teknologi Universitas 
Islam Negeri Maulana Malik Ibrahim' Malang.

Yuli, Y., 2014. 12 Manfaat Bawang Putih bagi Kesehatan dan Kulit (Teruji).https//manfaat.co.id/12 manfaatbawang putih-bagi-kesehatan-kulit-teruji.

Yuniastuti, K., 2006. Ekstraksi \& Identifikasi Komponen Sulfida pada Bawang Putih (Allium sativum L).Skripsi.Jurusan Kimia, Fakultas Matematika \& Ilmu Pengetahuan Alam Universitas Negeri Semarang. 